\section{Usefulness of dynamic compression bedside ultrasonography in the diagnosis of abdominal wall abscess}

\section{Bahjat Barakat, ${ }^{1}$ Raffaele Pezzilli² \\ 'Department of Emergency, S. Orsola- Malpighi University Hospital, Bologna; 2Department of Digestive System,}

S. Orsola-Malpighi University Hospital, Bologna, Italy

A 55 year-old male patient positive for HIV and chronic virus $\mathrm{C}$ hepatitis, medically treated for a previous left inguinal hernioplasty was admitted to emergency room because of 4-day long persistent non-specific pain of the left abdominal lower part. On admission at the emergency room, at physical examination there was pain on palpation midway between umbilicus and right inferior quadrant without rebound tenderness in the whole abdomen without erythema or skin warm. The rectal temperature was normal as well as cardiac and lung physical examination. Laboratory examination revealed an increase of white blood cells $\left(11.6310^{3} / \mathrm{mmc}\right.$, reference values 4.20 9.00) with $80 \%$ of neutrophils and C-reactive protein $6.17 \mathrm{mg} / \mathrm{dL}$ (upper reference limit 0.80 ). Renal, hepatic and coagulation parameters were within the normal limits. X-ray of the abdomen did not show alterations. A bedside dynamic compression ultrasound (US) showed a hypo-anechogenic area measuring $8.4 \mathrm{~cm}$ and $4.4 \mathrm{~cm}$ having fluctuating internal echoes, irregular margins of the left rectus abdominis muscle and swollen lymph nodes (Figure 1). To better define the US picture, a computed tomography (CT) scan was carried out, confirming the US picture (Figure 2). The abscess was surgically drained and the culture of the abscess revealed a Staphylococcus areus infection. The patient was discharged after 2 days with antibiotic therapy.

From an epidemiological point of view, the frequency of the abscess of soft tissue is increased in Western countries especially in HIV infected patients ${ }^{1}$ and the bacterium usually isolated is the Staphylococcus areus. ${ }^{2}$ The pathogenesis of this entity is unknown and probably HIV-infected patients are commonly colonized by Staphylococcus aureus. Neutrophils of these patients frequently have phagocytic, chemotactic, and oxidative defects and impaired bactericidal activity against Staphylococcus aureus. ${ }^{2}$ The diagnosis should be based on clinical signs such as pain. Dynamic compression ultrasound is usually the technique to easily detect the pyomyositis, ${ }^{3-6}$ while CT scan generally does not add any further useful information. The treatment is surgical and the follow-up is uneventful.

\section{References}

1. Al-Tawfiq JA, Sarosi GA, Cushing HE. Pyomyositis in the acquired immunodeficiency syndrome. South Med J 2000;93:330-4.

2. Schwartzman WA, Lambertus MW, Kennedy CA, Goetz MB. Staphylococcal pyomyositis in patients infected by the human immunodeficiency virus. Am J Med
Correspondence: Raffaele Pezzilli, Department of Digestive System, Sant'Orsola-Malpighi Hospital, via Massarenti 9, 40138 Bologna, Italy.

Tel: +39.051.6364148 - Fax: +39.051.6364148.

E-mail: raffaele.pezzilli@aosp.bo.it

Key words: Abscess abdominal wall; Ultrasonography; Computed tomography; High risk population.

Received for publication: 25 January 2015 . Accepted for publication: 2 February 2015.

This work is licensed under a Creative Commons Attribution 3.0 License (by-nc 3.0).

(C) Copyright B. Barakat and R. Pezzilli, 2015

Licensee PAGEPress, Italy

Emergency Care Journal 2015; 11:5068

doi:10.4081/ecj.2015.5068

1991;90:595-600.

3. Loyer EM, Kaur H, David CL, et al. Importance of dynamic assessment of the soft tissues in the sonographic diagnosis of echogenic superficial abscesses. J Ultras Med 1995;14:669-71.

4. Chau CL, Griffith JF. Musculoskeletal infections: ultrasound appearances. Clin Radiol 2005;60:149-59.

5. Kinare A, Brahmnalkar M, D'Costa S. Ultrasound of musculoskeletal soft tissue masses. Ind J Radiol Imag 2007;17:201-8.

6. Tichter A, Riley DC. Emergency department diagnosis of a quadriceps intramuscular loculated abscess/pyomyositis using dynamic compression bedside ultrasonography. Crit Ultrasound J 2013;5:3.

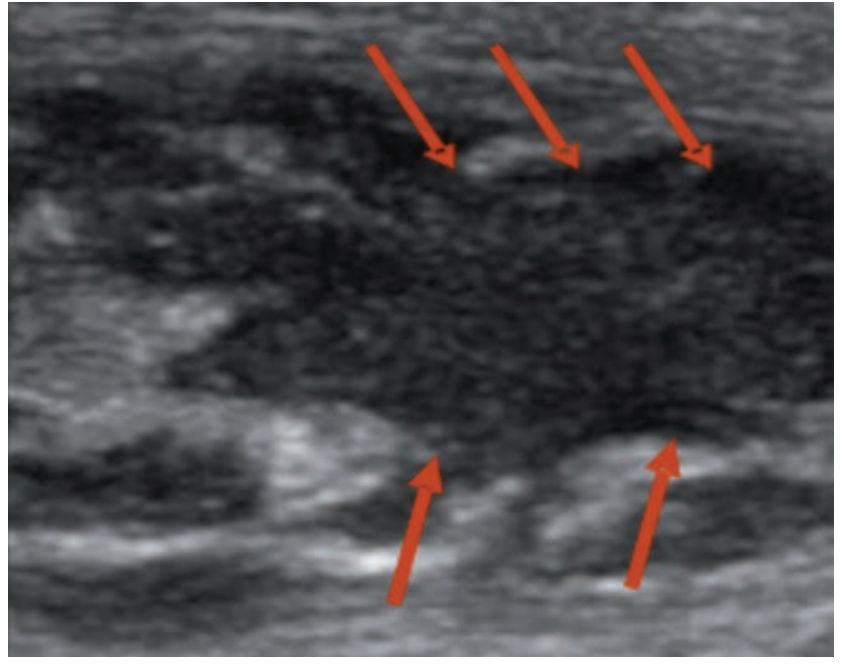

Figure 1. Bedside dynamic compression ultrasound showing a hypo-anechogenic area with fluctuating internal echoes, irregular margins of the left rectus abdominis muscle. The red arrows indicate the abscess.

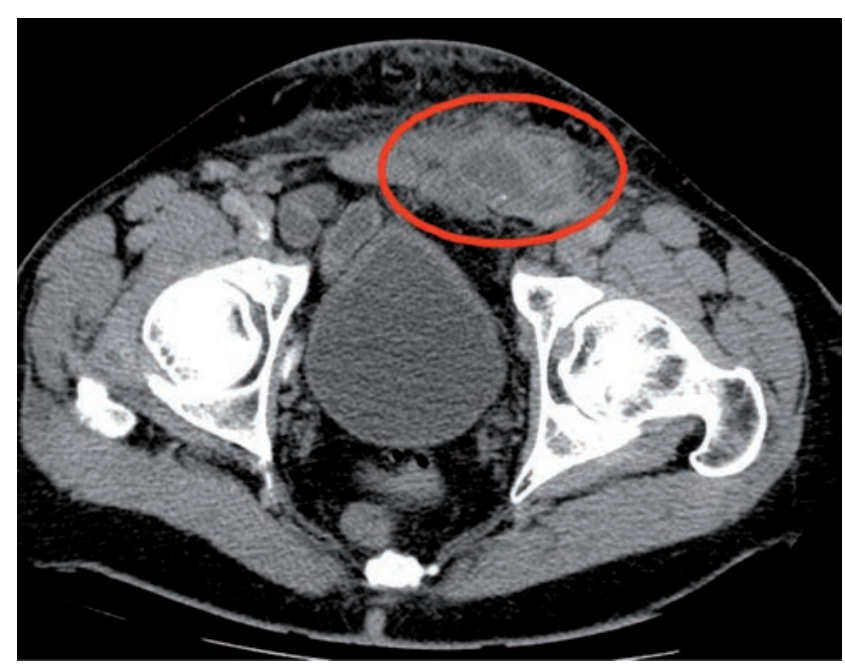

Figure 2. Contrast-enhanced computed tomography scan showing inhomogeneous soft tissue mass of the left rectus abdominis muscle, containing low and high-density structures. The abscess is indicated by a red circular line. 